\title{
Giant cell reparative granuloma of the proximal phalanx: A case report and literature review
}

\author{
A Perkins MD, A Izadpanah BSc, H Sinno MD MEng, C Bernard MD, HB Williams MD FRCS FACS
}

A Perkins, A Izadpanah, H Sinno, C Bernard, HB Williams. Giant cell reparative granuloma of the proximal phalanx: A case report and literature review. Can J Plast Surg 2011;19(2):e19-e21.

The present article is a case report of a 16-year-old boy who presented with a benign bony tumour, which on histological analysis suggested giant cell reparative granuloma (GCRG), but was not corroborate by blood tests. The implications of this type of tumour and the correct diagnostic requirements were investigated. The correct identification of GCRG from other giant cell-containing tumours is important because the treatment modalities for these tumours significantly differ from one another. In most cases, histological findings are sufficient to identify the tumours. In most GCRG cases, curettage is usually a curative treatment option. However, due to high recurrence rates of GCRGs, close follow-up of these patients is warranted. Also, due to osteoclastic activity of the giant cells in GCRGs, the use of drugs such as calcitonin or bisphosphonates, which inhibit osteoclast differentiation and activation, may have an important influence on future treatments or in reducing the recurrence rate of these tumours.

Key Words: Bony tumour; Giant cell granuloma; Phalanx

G iant cell reparative granuloma (GCRG) is a relatively uncom$\mathbf{J}_{\text {mon tumour of the maxilla and facial bones, and is rarely found }}$ in the phalanges. It is a benign tumour, but is locally destructive. Treatment usually requires surgical curettage of the affected region with filling of the dead space using autogenous bone graft or synthetic bone replacement. Normally, curettage as primary treatment is associated with a relatively high rate of local recurrence.

\section{CASE PRESENTATION}

A 16-year-old right-hand dominant boy presented to our outpatient clinic with pain on the palmar aspect of the middle finger of his left hand that had persisted for four months. He had a history of trauma that coincided with the onset of pain; otherwise, he was healthy. On closer examination, his left middle finger was tender, specifically on the distal aspect of the proximal phalanx.

A plain x-ray demonstrated a cortically based, lucent, well-delineated lesion on the distal volar aspect of the proximal phalanx (P1) of the left middle finger. There was minimal soft tissue swelling with no cortical breakthrough (Figure 1).

The patient was admitted to the operating room and, using a volar approach, the P1 of the left middle finger was exposed. Intraoperatively, the involved P1 appeared brown in colour and granular in nature. The specimen was curetted and sent for pathological analysis. The remaining P1 bone appeared adequately strong and was irrigated. The incision was closed in the normal fashion.

The patient's postoperative course was unremarkable, and he had full range of motion and stability. The patient underwent repeated $\mathrm{x}$-ray examinations performed eight months after the surgery that showed complete healing and a well-defined cortex (Figure 2).

The patient's pathological analysis revealed grossly small, brown, friable bony fragments $(1.2 \mathrm{~cm} \times 1.2 \mathrm{~cm} \times 0.2 \mathrm{~cm})$. Microscopic analysis revealed multiple fragments of bone with prominent connective

\section{Un granulome réparateur à cellules géantes de la phalange proximale : rapport de cas et analyse bibliographique}

Le présent article expose le rapport de cas d'un garçon de 16 ans qui a consulté à cause d'une tumeur osseuse bénigne qui, à l'analyse histologique, laissait supposer un granulome réparateur à cellules géantes (GRCG), ce qui n'était pas corroboré par les analyses sanguines. Les chercheurs ont évalué les répercussions de ce type de tumeur et les bonnes exigences diagnostiques. Il est important de bien distinguer les GRCG des autres tumeurs à cellules géantes, car les modalités thérapeutiques diffèrent énormément selon le type de tumeur. Dans la plupart des cas, les constatations histologiques suffisent pour distinguer les tumeurs. Dans la plupart des cas de GRCG, le curetage constitue généralement une possibilité de thérapie curative. Cependant, étant donné le fort taux de récurrence de GRCG, le suivi étroit de ces patients s'impose. De plus, en raison de l'activité ostéoclastique des cellules géantes des GRCG, le recours à des médicaments comme la calcitonine ou les bisphosphonates, qui inhibent la différenciation et l'activation ostéoclastiques, peut avoir une grande influence sur les futurs traitements ou sur la réduction du taux de récurrence de ces tumeurs.

tissue stroma composed of small oval and spindly mononuclear cells admixed with randomly distributed multinucleated osteoclast-like giant cells (Figure 3 ).

There were numerous small capillaries, hemorrhages and reactive bone formation with osteoblastic rimming, with no pleomorphism present in the specimen. No internal chondroid, osteoid matrix or periosteal reaction was found (Figure 4). The impression was a benign giant cell-rich lesion, favouring a diagnosis of GCRG of the bone. To exclude a brown tumour of hyperparathyroidism, calcium and parathyroid hormone levels were obtained, and were found to be normal.

\section{DISCUSSION}

GCRG was initially described in 1953 by Jaffe (1), who reported its occurrence in the maxilla and mandible. This lesion was initially believed to arise following a reactive process to intraosseous hemorrhage, such as jaw trauma; therefore, it was initially named 'giant cell reaction'. Later, Ackerman and Spjut (2) reported two cases of GCRG occurring in the small tubular bones of the hand. The term 'reparative' was added by Lorenzo and Dorfman (3) in 1980, noting its inconsistent association with trauma history.

GRCG is an uncommon, benign, destructive, osteolytic lesion that mostly affects the facial bones. GRCG is further classified into two distinct clinical forms: the peripheral type, involving the gingiva and alveolar mucosa; and the central type, which causes lytic destruction at the intraosseous level (4).

The most common clinical manifestations of GCRG include pain, swelling and palpable bone lesions (5). Although GCRG is described as a lytic lesion, the cortex usually remains intact (6). In the more aggressive type, cortical erosion and soft tissue expansion has been described $(7,8)$.

To determine the appropriate treatment regimen, it is important to distinguish GCRG from other giant cell-containing lesions such as giant cell tumours (GCTs), aneurysmal bone cysts, enchondromas and 


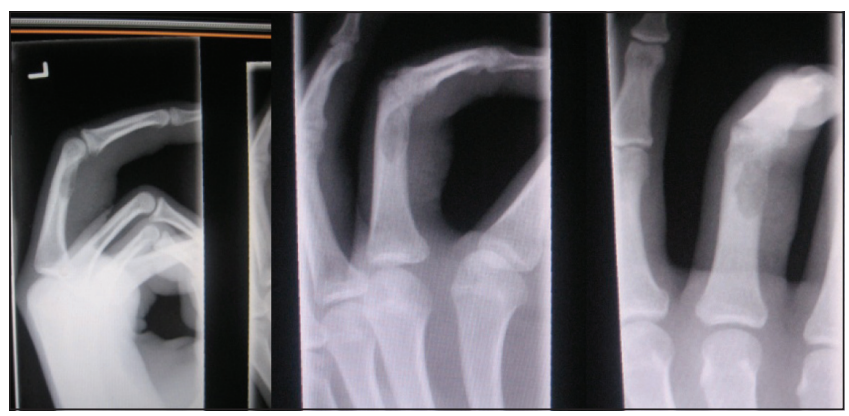

Figure 1) Left hand $x$-ray on presentation to outpatient clinic demonstrating a cortically based, lucent lesion on the distal velar aspect of the left middle finger

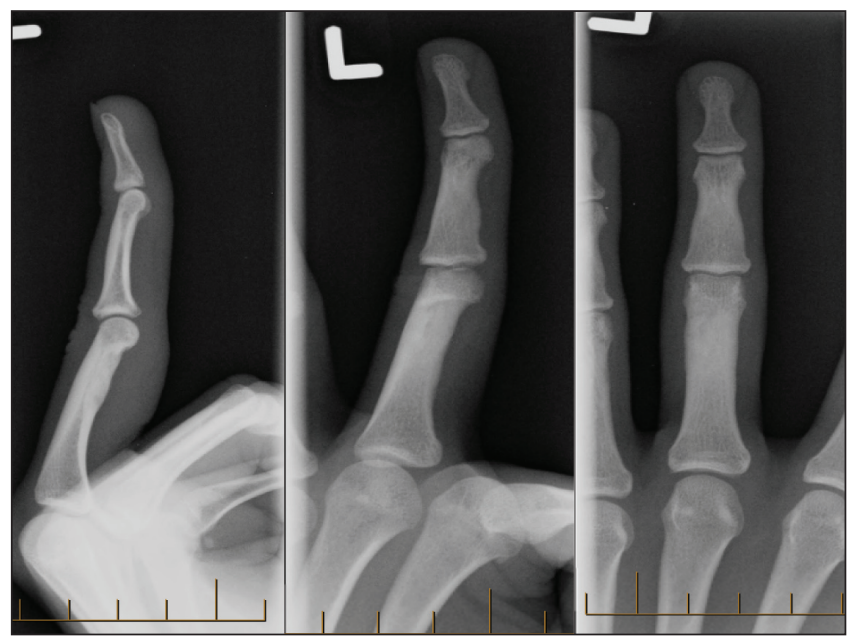

Figure 2) Left hand $x$-ray eight weeks postoperatively indicating complete healing and a well-defined cortex

brown tumours of hyperparathyroidism. Radiologically, GCRG is described as an expanding osteolytic lesion with contrast enhancement that thins and expands; however, usually does not perforate the cortex of the affected bone as described in the present case report $(9,10)$. Unfortunately, these radiographic features provide inadequate information to discriminate GCRG from other common bone lesions.

Histological examination of GCRGs could be useful in distinguishing them from GCTs. On histological examination, GCRG reveals a stromal component composed of spindle- to round-shaped cells, and multinucleated giant cells surrounding the foci of hemorrhage (9). It has been shown that round stromal cells of GRCG are capable of in vitro transformation of peripheral blood mononuclear cells to multinucleated giant cells, with osteoclast properties (7). On the other hand, histological examination of GCTs demonstrate homogenous stroma composed of giant and mononuclear cells distributed evenly throughout the tumour (11-13). GRCG occurs in patients in the second and third decades of life, with up to $74 \%$ of patients being younger than 30 years of age at the time of presentation (14). Unlike GCRG, GCT usually occurs in older patient populations, with an average age of 33 years (6). GCT is a more aggressive tumour, with a higher recurrence rate, and is commonly associated with soft tissue extension, which requires more aggressive treatment. A brown tumour of hyperparathyroidism is indistinguishable from GCRG on the basis of radiographic or histological features alone (15). In these cases, it is important to obtain serum calcium, phosphorous and parathyroid hormone levels to diagnose brown tumour of hyperthyroidism (3).

Recurrence rates in simple curettage of GRCGs are high, ranging from $33 \%$ to $75 \%(3,6,16,17)$. Therefore, the optimal treatment of choice for these tumours is complete surgical resection, which is associated with recurrence rates ranging from $10 \%$ to $20 \%$ (18). Unfortunately, wide resection of these tumours is associated with loss of function.
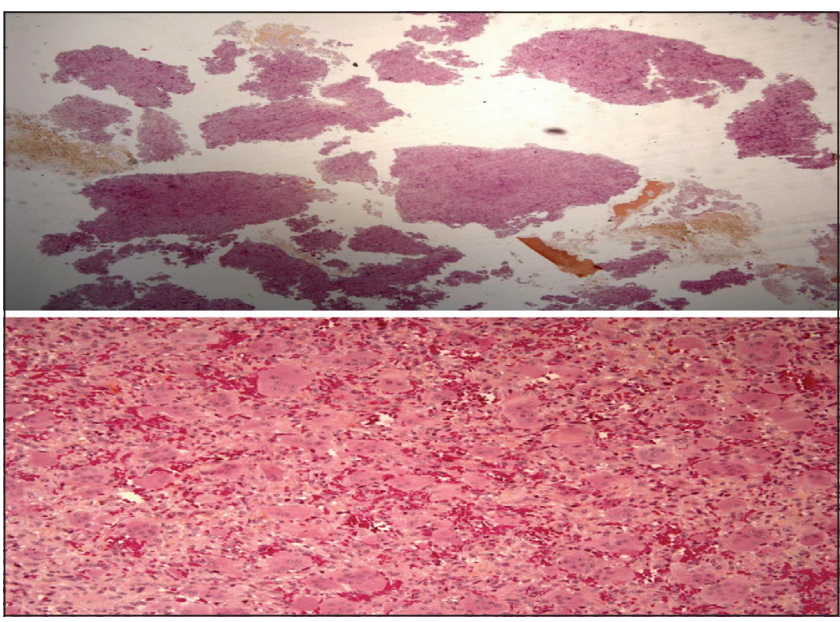

Figure 3) Histopathological examination of curetted bone showing multiple fragments of bone with prominent connective tissue stroma composed of small, oval mononuclear cells

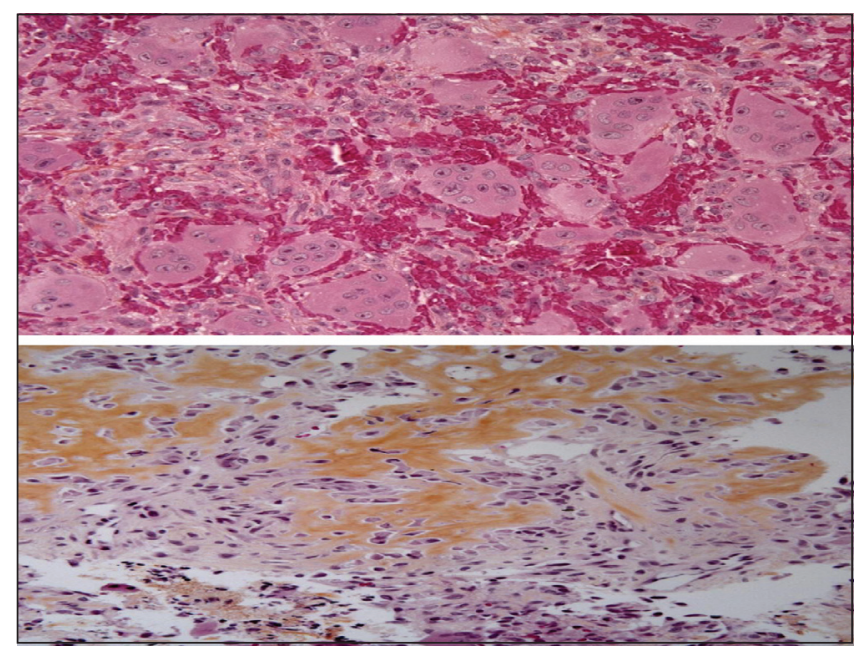

Figure 4) Higher power histological evaluation of the specimen showing numerous small capillaries, hemorrhages and reactive bone formation with no pleomorphism

Therefore, many surgeons have attempted adjuvant therapy to reduce use of extreme invasive modalities for treatments of GCRGs. Postcurettage adjuvant treatment modalities, such as liquid nitrogen, could reduce the recurrence rate to as low as $8 \%$ (19). Ethanol or phenol application $5 \mathrm{~min}$ to $10 \mathrm{~min}$ after curettage have also been shown to reduce the recurrence rate to as low as $10 \%(20,21)$.

\section{CONCLUSIONS}

The correct identification of GCRG from other giant cell-containing tumours is important because the treatment modalities for these tumours significantly differ from one another. In most cases, histological findings are sufficient to identify these tumours. In most cases of GCRGs, curettage is usually a curative treatment option. However, due to the high recurrence rate of GCRGs, close follow-up of these patients is warranted. Also, due to osteoclastic activity of the giant cells, the use of drugs such as calcitonin or bisphosphonates, which inhibit osteoclast differentiation and activation, may have an important influence on future treatments or in reducing the recurrence rate of these tumours.

\section{REFERENCES}

1. Jaffe HL. Giant-cell reparative granuloma, traumatic bone cyst, and fibrous (fibro-oseous) dysplasia of the jawbones. Oral Surg Oral Med Oral Pathol 1953;6:159-75. 
2. Ackerman LV, Spjut HJ. Giant cell reaction in tumors of bones and cartilage. In: Spjut HJ, Dorfman HD, Fechner RE, Ackerman LV, Atlas of Tumor Pathology. Washington: Armed Forces Institute of Pathology, 1962:282.

3. Lorenzo JC, Dorfman HD. Giant-cell reparative granuloma of short tubular bones of the hands and feet. Am J Surg Pathol 1980;4:551-63.

4. Montero EH, Navarro JS, Pueyo JL, Garca Fde M, Sampériz LC, Garca AO. Giant-cell reparative granuloma in the temporal bone. Am J Otolaryngol 2003;24:191-3.

5. Resnick D. Tumors and tumor-like lesions of bone. Diagnosis of Bone and Joint Disorders. Philadelphia: WB Sanders, 1995:3805-6.

6. Ratner V, Dorfman HD. Giant-cell reparative granuloma of the hand and foot bones. Clin Orthop Relat Res 1990;260:251-8.

7. Giza E, Stern PJ, Cualing H. Aggressive giant cell reparative granuloma of the metacarpal: A case report. J Hand Surg Am 1997;22:732-6.

8. Bertoni F, Biscaglia R, Bacchini P. Giant cell reparative granuloma of the phalanx of the hand with aggressive radiographic features. Skeletal Radiol 1998;27:584-7.

9. Hirschl S, KatzA. Giant cell reparative granuloma outside the jaw bone. Diagnostic criteria and review of the literature with the first case described in the temporal bone. Hum Pathol 1974;5:171-81.

10. Dimitrakopoulos I, Lazaridis N, Sakellariou P, Asimaki A. Giant-cell granuloma in the temporal bone: A case report and review of the literature. J Oral Maxillofac Surg 2006;64:531-6.

11. Forouhar FA, Phelan NP, Benton DC. Giant cell reparative granuloma of the small bones of the hands and feet: A report of three cases. Ann Clin Lab Sci 2000;30:272-7.
12. Wold LE, Dobyns JH, Swee RG, Dahlin DC. Giant cell reaction (giant cell reparative granuloma) of the small bones of the hands and feet. Am J Surg Pathol 1986;10:491-6.

13. Picci P, Baldini N, Sudanese A, Boriani S, Campanacci M. Giant cell reparative granuloma and other giant cell lesions of the bones of the hands and feet. Skeletal Radiol 1986;15:415-21.

14. Waldron CA, Shafer WG. The central giant cell reparative granuloma of the jaws. An analysis of 38 cases. Am J Clin Pathol 1966;45:437-47.

15. Murphey MD, Nomikos GC, Flemming DJ, Gannon FH, Temple HT, Kransdorf MJ. From the archives of AFIP. Imaging of giant cell tumor and giant cell reparative granuloma of bone: Radiologic-pathologic correlation. Radiographics 2001;21:1283-309.

16. Caskey PM, Wolf MD, Fechner RE. Multicentric giant cell reparative granuloma of the small bones of the hand. A case report and review of the literature. Clin Orthop Relat Res 1985;193:199-205.

17. Wenner SM, Johnson K. Giant cell reparative granuloma of the hand. J Hand Surg Am 1987;12:1097-101.

18. Souter MA, Bird PA, Worthington JP. Giant cell reparative granuloma of the temporal bone treated with calcitonin. Otol Neurotol 2006;27:999-1002.

19. Daniel W. Progress in the treatment of giant cell tumor of bone. Curr Opin Orthop 1999;10:474-80.

20. Oh JH, Yoon PW, Lee SH, Cho HS, Kim WS, Kim HS, Surgical treatment of giant cell tumour of long bone with anhydrous alcohol adjuvant. Int Orthop 2006;30:490-4.

21. Durr HR, Jansson V, Baur A, Refior HJ. Phenol as an adjuvant for local control in the treatment of giant cell tumour of the bone. Eur J Surg Oncol 1999;25:610-8. 